\title{
ON THE RENAL SITE AND MODE OF ACTION OF GLUCOCORTICOID IN CIRRHOSIS *
}

\author{
BY HERSHEL JICK, $\dagger$ JULIAN G. SNYDER, ELLIOT M. FINKELSTEIN, JOSEPH \\ L. COHEN, EDWARD W. MOORE, AND ROBERT S. MORRISON \\ (From the Clinical Pharmacology and Renal and Electrolyte Divisions of the Medical Service, \\ Lemuel Shattuck Hospital, Department of Public Health, Commonwealth of \\ Massachusetts, and the Departments of Medicine, Harvard Medical School \\ and Tufts University School of Medicine, Boston, Mass.)
}

(Submitted for publication March 21, 1963; accepted June 13, 1963)

The mechanism of action of glucocorticoid in the kidney has been the subject of much speculation. Few studies with these agents, however, have been reported that help elucidate their apparently paradoxical effects of sodium retention, initially, in normal subjects $(1,2)$ and marked diuretic potentiation in many patients with fluid retention (3-6). Thus their mechanism of action has remained unknown, owing in part to the inability of investigators to demonstrate acute renal effects of these agents in subjects with intact adrenals. Careful studies on the effects of chronic administration have been done, but specific interpretation has been difficult because many variables of renal function cannot be continuously followed over extended periods $(3,7)$.

While natruresis has been observed in some patients with fluid retention who were given glucocorticoid alone $(4,6)$, an increase in urine volume without accompanying increase in sodium excretion was observed by Kessler, Hilton, and Levy (3) and Morrison and Chalmers (5). Kessler and associates showed an increased ability to excrete free water during a water load in their patients during treatment with glucocorticoid (3). Careful studies indicate that changes in antidiuretic hormone release (8) are not the primary explanation of the effect on water excretion $(7,9)$, and therefore the mechanism appears to be on the kidney.

The present studies were designed to localize the primary site of action of glucocorticoids in the kidney. Since potentiation of diuresis is marked

\footnotetext{
* Investigation supported by U. S. Public Health Service grants $\mathrm{H}-4789, \mathrm{H}-2324$, and A-2334.

+ Work done during tenure of Clinical Pharmacology Traineeship, awarded to Harvard and Tufts Universities by the National Heart Institute.
}

in cirrhotics, patients with cirrhosis on a low-salt diet were studied. The data indicate that these agents given acutely cause increased reabsorption of sodium in the ascending loop of Henle, a segment of the tubule that is relatively impermeable to water, and thus increase the capacity of the kidney of these patients to conserve free water.

\section{METHODS}

Chronic and acute studies of several types were done in a group of 16 patients with cirrhosis of the liver of varying severity associated with chronic alcoholism. None of the patients gave a history of renal disease, and all had a normal urinalysis, nonprotein nitrogen, and serum creatinine concentration.

For clarity, the protocols of each type of study are given with the results. The following measurements and chemical determinations were made: body weight, urine volume, and urine and plasma sodium, potassium, and osmolality. Maximal urine osmolality $\left(U_{\max }\right)$ was obtained after overnight dehydration and im vasopressin tannate in oil at bedtime. Negative free water clearance $\left(\mathrm{T}^{\mathrm{c}} \mathrm{H}_{2 \mathrm{O}}\right)$ was determined by inducing osmotic diuresis with $10 \%$ mannitol and aqueous Pitressin (vasopressin). Clearance of inulin $\left(C_{1 n}\right)$ was determined during the rapid mannitol infusion after a priming dose of inulin. At least three collection periods were obtained and averaged.

Urine and plasma osmolality were determined with a Fiske model B cryoscopic osmometer. Sodium and potassium concentrations were determined with a Baird model DB-4 flame photometer. Inulin was determined by the resorcinol method for fructose of Bacon and Bell as modified by Higashi and Peters (10). Mannitol was determined by the method of Corcoran and Page (11). Total solute clearance $\left(\mathrm{C}_{\mathrm{osm}}\right)$ was calculated from the formula $\mathrm{C}_{o s m}=\left(\mathrm{U}_{\mathrm{osm} m} / \mathrm{P}_{\mathrm{osm}}\right) \mathrm{V}$. (U $\mathrm{U}_{\mathrm{osm}}=$ urine osmolality, $\mathrm{P}_{\mathrm{osm}}=$ plasma osmolality, $\mathrm{V}=$ rate of urine flow.) $T^{c_{H_{2} O}}$ was calculated from the formula $T^{c_{H_{2} \mathrm{O}}}=C_{o s m}-V$.

\section{PROTOCOLS AND RESULTS}

Chronic studies. Three patients were observed on a metabolic ward for 22 days, during which 


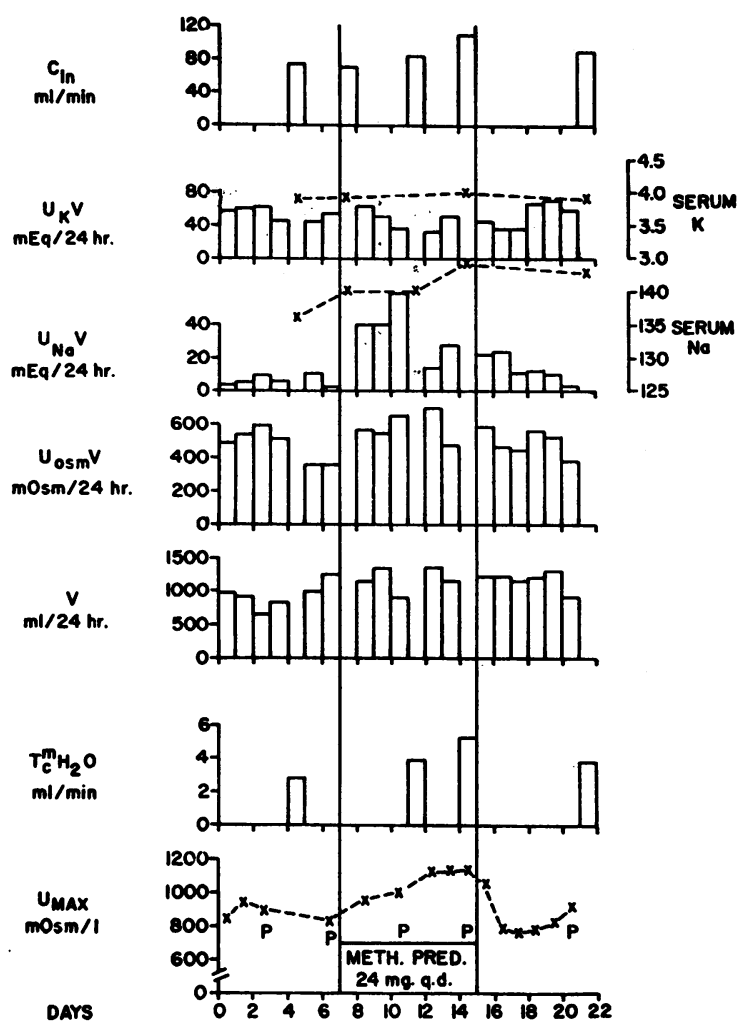

Fig. 1. EFfects of 8-DAY administration OF METH YL PREDnisolone IN Patient 1. Twenty-four hour data are not included for clearance days. $\mathrm{P}=$ Pitressin in oil.

their daily intake of fluid was constant and intake of solid food was relatively constant. The diet contained $9 \mathrm{mEq}$ of sodium each day and at least $75 \mathrm{~g}$ of protein.

On either day 4 or 5 , serum sodium, potassium, $\mathrm{U}_{\max }, \mathrm{T}^{\mathrm{c}}{ }_{\mathrm{H}_{2} \mathrm{O}},{ }^{1}$ and $\mathrm{C}_{\mathrm{in}}$ were determined. From days 8 through 15 , each patient received either 24 or $32 \mathrm{mg}$ of methyl prednisolone daily, in divided doses. On the first, fifth, and eighth days of steroid administration (days 8,12 , and 15 ), serum sodium, potassium, $C_{i n}$, and $U_{\max }$ were determined. $\mathrm{T}^{\mathrm{c}}{ }_{\mathrm{H}_{2} \mathrm{O}}$ was determined on the latter two clearance days (days 12 and 15). The drug was discontinued on day 16 , and serum sodium, potassium, $\mathrm{C}_{\mathrm{in}}, \mathrm{U}_{\max }$, and $\mathrm{T}^{\mathrm{c}}{ }_{\mathrm{H}_{2} \mathrm{O}}$ were again determined on the final day of observation (day 22).

Patient 1 was in remission after a recent episode of jaundice and ascites. She had no demonstrable

${ }_{1} \mathrm{~T}^{\mathrm{c}}{ }_{\mathrm{H}_{2} \mathrm{O}}$ values given in results represent the average of at least two values obtained above a $\mathrm{C}_{0 \mathrm{sm}}$ of $12 \mathrm{ml}$ per minute. fluid retention and was able to handle a salt load without gaining weight. Patients 2 and 3 had moderate ascites and developed further ascites when dietary sodium was increased before this study.

The results of 8-day administration of methyl prednisolone are shown in Figures 1, 2, and 3. Consistent findings were: 1) mild increase in 24hour sodium excretion, which rose during the first few days and then maintained a relatively constant level; 2) marked elevation of $\mathrm{T}^{\mathrm{c}} \mathrm{H}_{2} \mathrm{O}$-a progressive rise occurred in all three patients, and $\mathrm{T}^{\mathrm{c}} \mathrm{H}_{2} \mathrm{O}$ reached normal values in each despite the fact that dietary sodium remained restricted; 3 ) elevation in $U_{\max }$ - each patient showed a rise in $\mathrm{U}_{\max }$ that appeared to be gradual; in Patient 3 , the rise continued for a short period after steroid was stopped, but then fell; 4) elevation of serum sodium-each patient showed a small rise in the serum sodium even though the original values were within normal limits; a rather dramatic fall occurred in Patients 2 and 3 after the drug was stopped.

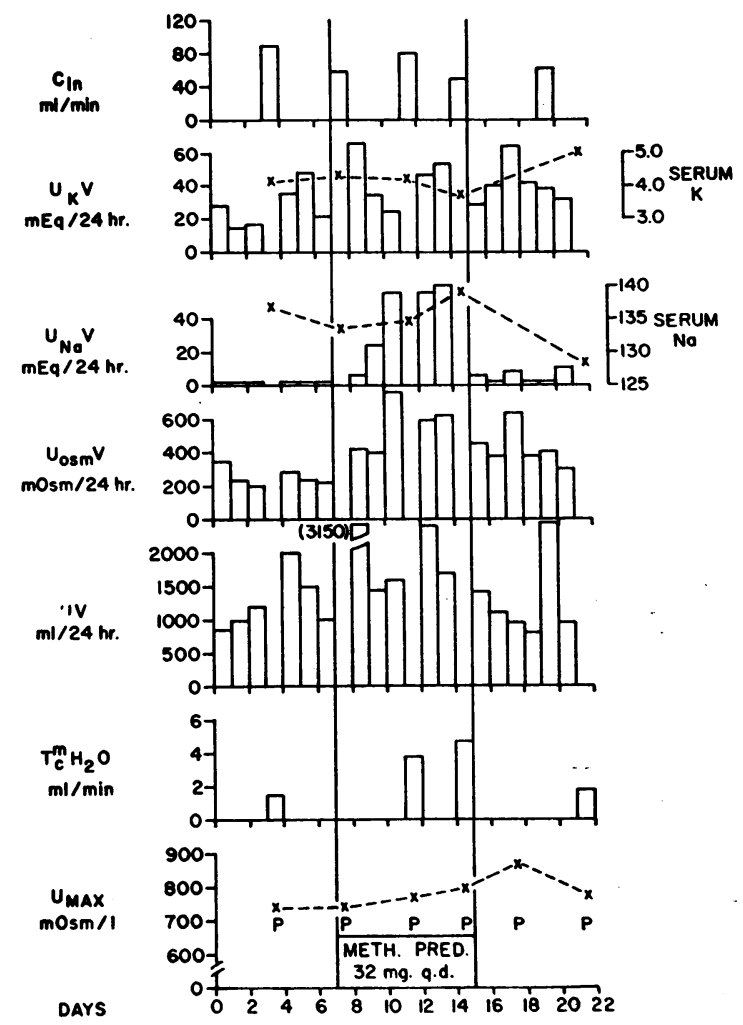

Fig. 2. EFfects of 8-DAy administration of MEthyL PREDNISOLONE IN PATIENT $2 . \quad \mathrm{P}=$ Pitressin in oil. 


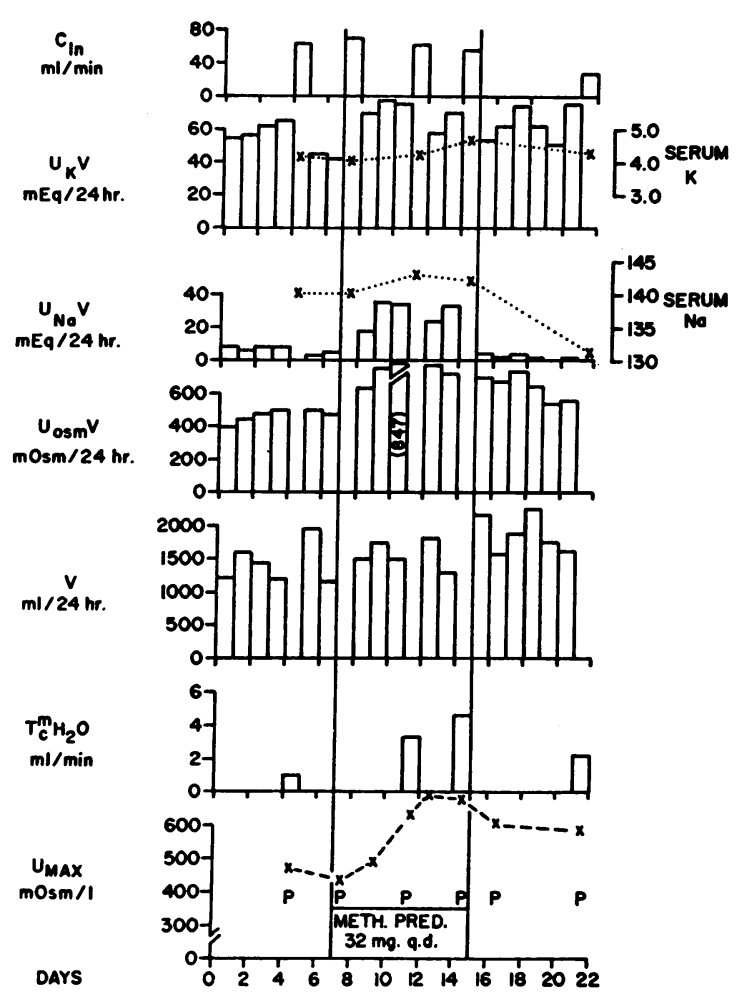

Fig. 3. EFFects of 8-DAy ADMINistration OF METhYL PREDNisolone in Patient 3. $\mathrm{P}=$ Pitressin in oil.

Each of the changes above returned to control levels or below after the drug was stopped. Effects on potassium excretion, solute excretion, and urine volume were variable, although each usually rose slightly during drug administration. $\mathrm{C}_{\mathrm{in}}$ rose in Patient 1 and appeared to be unchanged in Patients 2 and 3. Both mannitol and Pitressin were given frequently during the entire study, and these undoubtedly affected many of the 24-hour values.

Acute studies. All patients in these studies were receiving $9 \mathrm{mEq}$ of dietary sodium per day and were given nothing by mouth for 16 hours and $5 \mathrm{U}$ im vasopressin tannate in oil 12 hours before study. Each patient received a priming infusion of inulin (except Patients 11 through 16) and aqueous Pitressin. Urines were collected throughout the studies either by indwelling urinary catheter or by voluntary voiding. All urines and bloods obtained during acute studies were analyzed for sodium, potassium, osmolality, mannitol (except in Patient 12), and inulin (except in Patients 11 through 16).

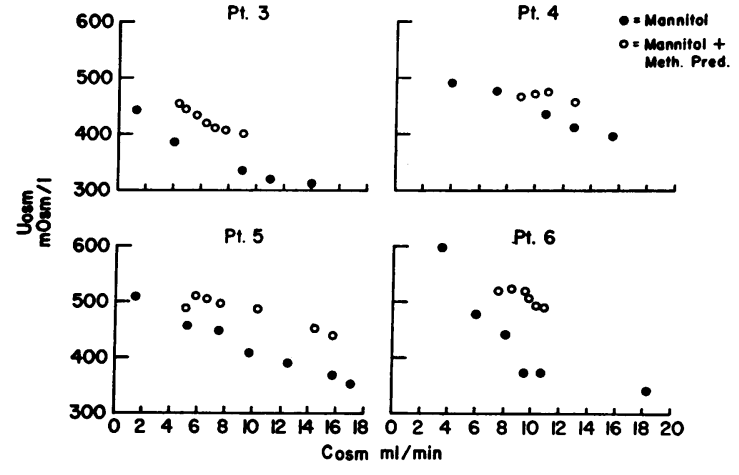

Fig. 4. Graphs of Uosm against $\mathrm{C}_{\text {osm }}$ with and WITHOUT METHYL PREDNISOLONE DURING MANNITOL DIURESIS.

1) Four patients were studied during an iv infusion of $10 \%$ mannitol at a steady rate of either 80 or 120 drops per minute. Urine was collected every 15 to 30 minutes, and blood was obtained during these intervals. After 2 to $2 \frac{1}{2}$ hours, each patient was given $40 \mathrm{mg}$ of iv methyl prednisolone, and urine and blood collections were continued for at least $2 \frac{1}{2}$ hours. The rate of infusion was subsequently increased to obtain urines over a larger range of $\mathrm{C}_{\text {osm. }}$. On a previous day, osmotic diuresis had been induced in each patient with $10 \%$ mannitol to obtain control values of $U_{\text {osm }}$ and sodium excretion $\left(\mathrm{U}_{\mathrm{Na}} \mathrm{V}\right)$ over a wide range of $\mathrm{C}_{\text {osm }}$.

The effects of iv methyl prednisolone were consistent in the four patients studied according to this protocol, in which $\mathrm{T}^{\mathrm{c}}{ }_{\mathrm{H}_{2} \mathrm{O}}$ was measured on two

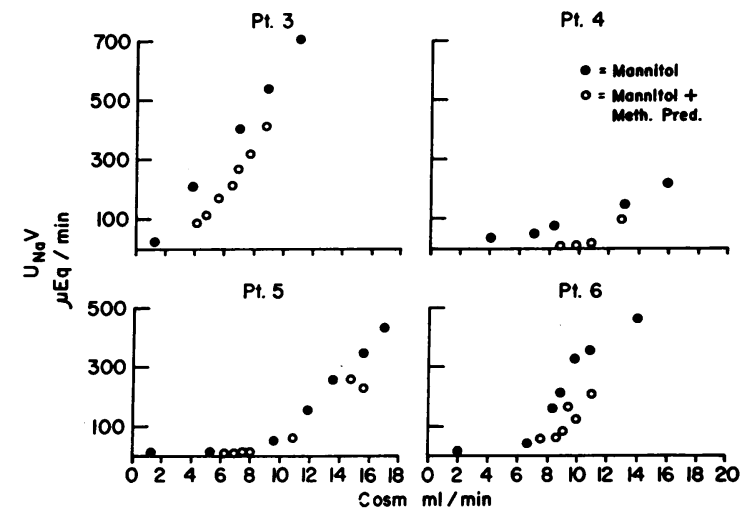

Fig. 5. Graphs of $U_{\mathrm{Na}} \mathrm{V}$ against $\mathrm{C}_{\text {osm }}$ With and WITHOUT METHYL PREDNISOLONE DURING MANNITOL DIURESIS. 
TABLE: I

Detailed protocol of acute experiment $A$ in Patient 3

\begin{tabular}{|c|c|c|c|c|c|c|c|c|}
\hline Time & Vol & U $_{\text {osm }}$ & $\mathrm{C}_{\text {osm }}$ & $\mathrm{T}^{\mathrm{c}} \mathrm{H}_{2} \mathrm{O}$ & $\mathrm{UNaV}_{\mathrm{Na}}$ & Posm & $C_{\text {in }}$ & $\mathrm{C}_{\operatorname{man}}$ \\
\hline $\min$ & $m l / m i n$ & $\mu O s m / m l$ & $m l / m i n$ & $m l / m i n$ & $\underset{\min }{\mu E q /}$ & $\underset{m l}{\mu O s m /}$ & $m l / m i n$ & $\operatorname{ml} / \min$ \\
\hline \multicolumn{9}{|l|}{ Day 1} \\
\hline-60 to & 0.9 & 509 & 1.6 & 0.7 & $<1$ & & & \\
\hline \multicolumn{9}{|c|}{ Rapid infusion of $10 \%$ mannitol with aqueous Pitressin } \\
\hline $\begin{array}{r}0 \text { to }+18 \\
+18 \text { to }+28 \\
+28 \text { to }+37 \\
+37 \text { to }+47 \\
+47 \text { to }+56 \\
+56 \text { to }+67 \\
+67 \text { to }+77\end{array}$ & $\begin{array}{r}3.2 \\
4.5 \\
7.0 \\
9.8 \\
10.9 \\
13.4 \\
14.2\end{array}$ & $\begin{array}{l}463 \\
455 \\
418 \\
389 \\
374 \\
364 \\
358\end{array}$ & $\begin{array}{r}5.1 \\
7.0 \\
9.8 \\
12.7 \\
13.6 \\
16.2 \\
16.9\end{array}$ & $\begin{array}{l}1.9 \\
2.5 \\
2.8 \\
2.9 \\
2.7 \\
2.8 \\
2.7\end{array}$ & $\begin{array}{r}3.2 \\
43 \\
150 \\
257 \\
330 \\
430\end{array}$ & 290 & & \\
\hline \multicolumn{9}{|l|}{ Day 2} \\
\hline $\begin{array}{l}-180 \\
-160 \\
-120 \text { to }-90 \\
-90 \text { to }-64 \\
-64 \text { to }-24 \\
-24 \text { to } 0\end{array}$ & $\begin{array}{l}\text { Inulin } \\
10 \% \\
2.6 \\
2.7 \\
2.9 \\
3.0\end{array}$ & $\begin{array}{l}\text { iming wit } \\
\text { nnitol wit } \\
481 \\
499 \\
493 \\
500\end{array}$ & $\begin{array}{c}\text { queous } \\
\text { nulin an } \\
4.2 \\
4.6 \\
4.8 \\
5.1\end{array}$ & $\begin{array}{c}\text { ressin } \\
\text { queous } \\
1.6 \\
1.9 \\
1.9 \\
2.1\end{array}$ & $\begin{array}{c}\text { ssin at } \\
23 \\
17 \\
14 \\
19\end{array}$ & $\begin{array}{c}\text { drops p } \\
295 \\
294 \\
\\
294\end{array}$ & $\begin{array}{c}\text { minute } \\
77 \\
63 \\
57 \\
58\end{array}$ & $\begin{array}{l}64 \\
54 \\
59\end{array}$ \\
\hline \multicolumn{9}{|c|}{$40 \mathrm{mg}$ iv methyl prednisolone } \\
\hline $\begin{array}{r}0 \text { to }+41 \\
+41 \text { to }+58 \\
+58 \text { to }+78 \\
+78 \text { to }+97\end{array}$ & $\begin{array}{l}3.5 \\
3.4 \\
3.8 \\
4.5\end{array}$ & $\begin{array}{l}492 \\
514 \\
510 \\
500\end{array}$ & $\begin{array}{l}5.7 \\
5.8 \\
6.5 \\
7.5\end{array}$ & $\begin{array}{l}2.2 \\
2.4 \\
2.7 \\
3.0\end{array}$ & $\begin{array}{l}30 \\
32 \\
41 \\
56\end{array}$ & $\begin{array}{l}295 \\
297\end{array}$ & $\begin{array}{l}62 \\
56 \\
62 \\
71\end{array}$ & $\begin{array}{l}64 \\
63 \\
73 \\
77\end{array}$ \\
\hline \multicolumn{9}{|c|}{$10 \%$ mannitol increased to 120 drops per minute } \\
\hline $\begin{array}{l}+97 \text { to }+108 \\
+108 \text { to }+122 \\
+122 \text { to }+132\end{array}$ & $\begin{array}{r}6.2 \\
9.8 \\
10.8\end{array}$ & $\begin{array}{l}492 \\
442 \\
426\end{array}$ & $\begin{array}{l}10.2 \\
14.7 \\
15.3\end{array}$ & $\begin{array}{l}4.0 \\
4.9 \\
4.5\end{array}$ & $\begin{array}{l}118 \\
283 \\
238\end{array}$ & & & \\
\hline
\end{tabular}

separate days, with and without methyl prednisolone (Figures 4 and 5, Table I). Plasma mannitol levels were still rising when the drug was given, and since the clearance of mannitol $\left(\mathrm{C}_{\operatorname{man}}\right)$ did not change significantly during these studies, $\mathrm{C}_{\text {osm }}$ continued to rise also, following methyl prednisolone. Values for $\mathrm{U}_{\mathrm{osm}}$ and $\mathrm{U}_{\mathrm{Na}} \mathrm{V}$ were compared with values obtained during a control mannitol infusion. $\mathrm{U}_{\text {osm }}$ (and therefore $\mathrm{T}^{\mathrm{c}} \mathrm{H}_{2} \mathrm{O}$ ) was always higher for a given $\mathrm{C}_{\text {osm }}$ after the drug than during the control mannitol infusion without methyl prednisolone on a previous day. Sodium excretion was always lower.

2) A group of ten patients was studied by the same protocol as in A, above, except that a priming infusion of $500 \mathrm{ml}$ of $10 \%$ mannitol was given at 25 to $30 \mathrm{ml}$ per minute before a steady infusion at 80 drops per minute was started. In order to ensure a relatively steady state, the steroid was given only after the urine osmolality, measured during the procedure, appeared to be stabilized.
Three of the patients (no. 14, 15, and 16) were used as controls, and no steroid was given as the infusion continued. Patients 12,13 , and 16 were in remission after previous episodes of jaundice and ascites. Liver function tests in these patients were normal, and there was no evidence of fluid retention. The other patients studied acutely had evidence of active liver disease and fluid retention.

With this protocol, relatively constant serum and urine mannitol levels were obtained on the same day, before and after methyl prednisolone (Figures 6, 7, and 8, Tables II and III). Since $\mathrm{C}_{\text {osm }}$ did not rise significantly after methyl prednisolone was given, the effects of the agent could be observed independently of substantial changes in $\mathrm{C}_{\text {osm }}$.

All patients given steroid showed a decrease in sodium excretion (Tables II and III). The decrease usually began at 30 to 45 minutes after the drug was given and varied from about 9 to $53 \%$ 


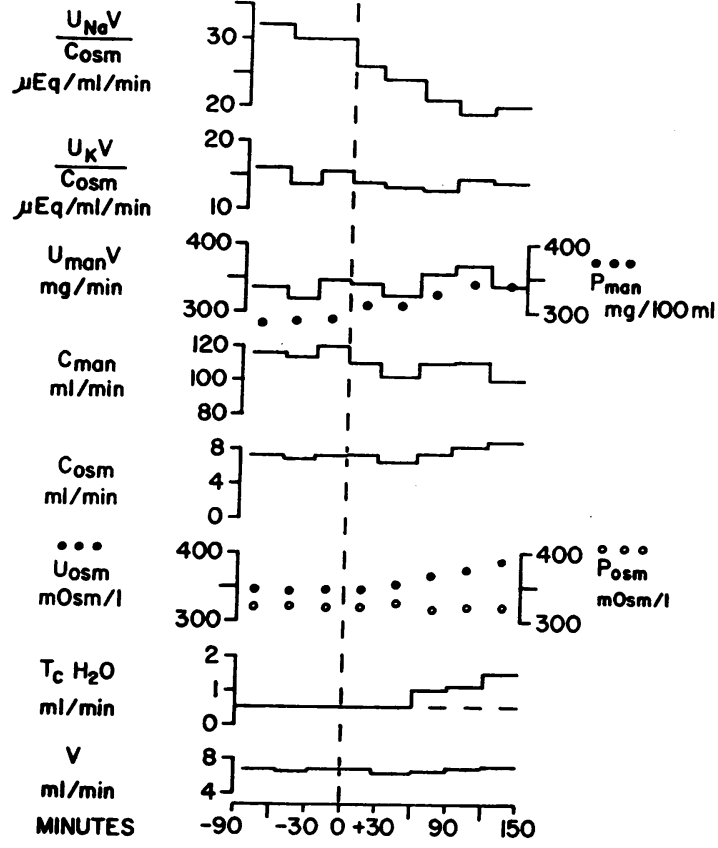

Fig. 6. Results of a Representative study Showing EFFECTS OF 40 MG OF IV METHYL PREDNISOLONE IN PATIENT 10.

of control values and from about 19 to $240 \mu \mathrm{Eq}$ per minute. The mean decrease was $86 \pm 32 \mu \mathrm{Eq}$ per minute $(1 \mathrm{SE})(\mathrm{p}<.05)$ (Figures 6 and 7 , Table III). Control patients had no significant change in sodium excretion (Figure 8). Because of slight variation in $\mathrm{C}_{\text {osm }}$ due to occasional incomplete voiding, sodium excretion is plotted as the ratio of $\mathrm{U}_{\mathrm{Na}} \mathrm{V} / \mathrm{C}_{\mathrm{osm}}$ in Figures 6,7 , and 8.

$\mathrm{U}_{\text {osm }}$ rose steadily after iv methyl prednisolone. This rise usually persisted until the experiment was discontinued, and the increase in $\mathrm{U}_{\text {osm }}$ was reflected by a small but highly reproducible increase in $\mathrm{T}^{\mathrm{c}} \mathrm{H}_{2} \mathrm{O}$ that began at the same time as or shortly after the decrease in sodium excretion (Figures 6 and 7 , Tables II and III). The increase ranged from 0.3 to $1.1 \mathrm{ml}$ per minute. The mean increase was $0.6 \pm 0.07 \mathrm{ml}$ per minute $(\mathrm{p}<.001)$ Table III). There was no significant change in $\mathrm{T}^{\mathrm{c}}{ }_{\mathrm{H}_{2} \mathrm{O}}$ in control patients (Figure 8).

No significant effect on potassium excretion was noted under the conditions of this experiment (Table III).

Both $C_{i n}$ and $C_{\operatorname{man}}$ (mannitol clearance) were measured in eight patients and found to be comparable. The ratio of $C_{\operatorname{man}}$ to $C_{i n}$ equaled $1.09 \pm$

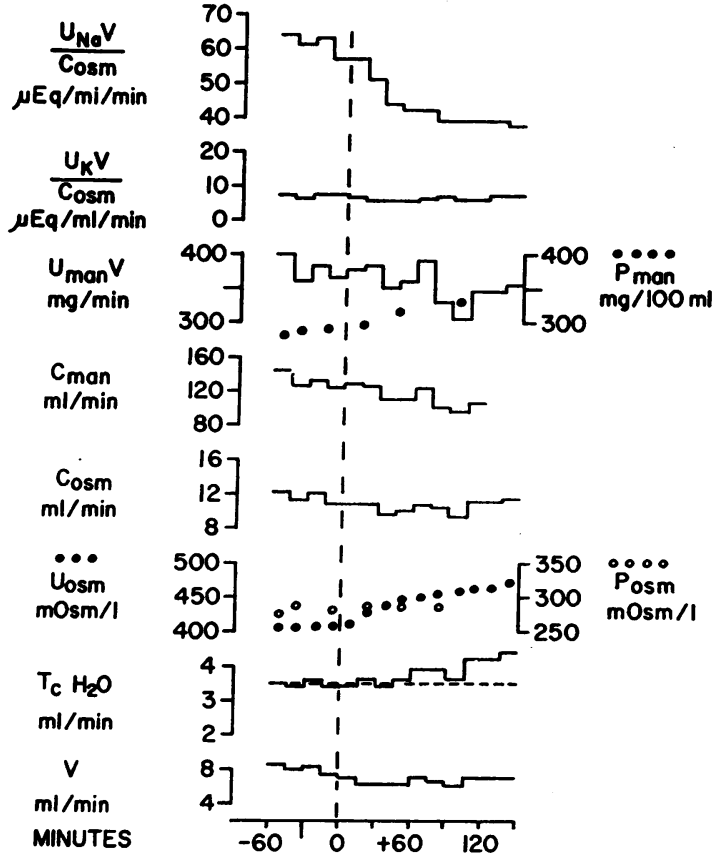

Fig. 7. EfFects of 40 Mg of IV MEthyl PREDNisolone in Patient 11.

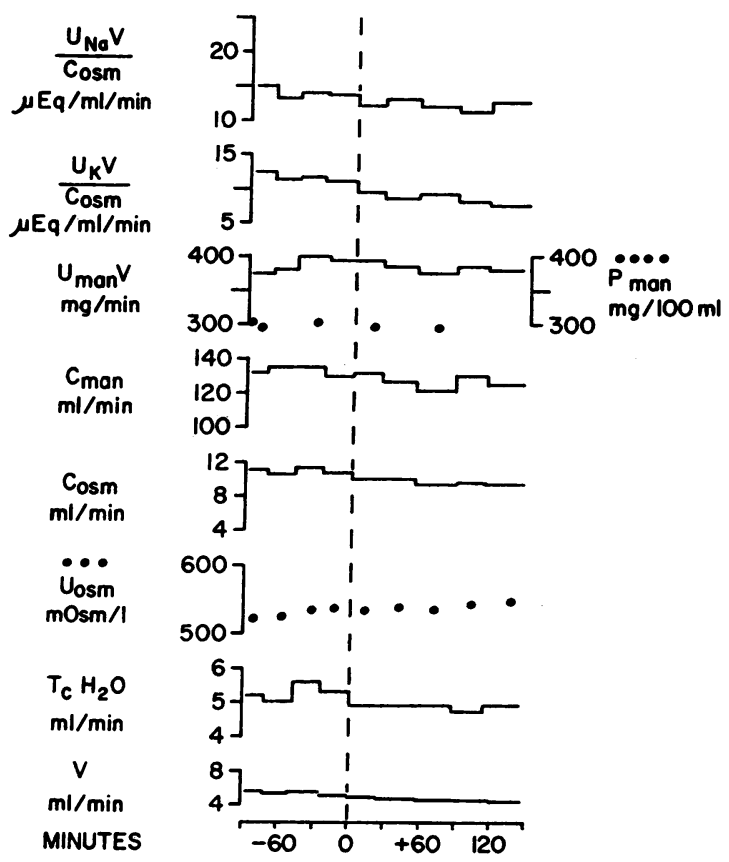

Fig. 8. Control experiment in Patient 14: effects OF IV MANNITOL WITHOUT METHYL PREDNISOLONE. Vertical line represents time when methyl prednisolone would have been given if this were not a control experiment. 
TABLE II

Detailed protocol of acute experiment B in Patient 13

\begin{tabular}{|c|c|c|c|c|c|c|c|c|c|c|}
\hline Time & Vol & Uosm & Cosm & $\mathrm{T}^{\mathrm{C}} \mathrm{H}_{2} \mathrm{O}$ & $\frac{\mathrm{U}_{\mathrm{NaV}}}{\mathrm{C}_{\mathrm{osm}}}$ & $\frac{\mathrm{UKV}_{\mathrm{K}}}{\mathrm{C}_{\mathrm{osm}}}$ & $U_{\operatorname{man}} \mathrm{V}$ & $\mathrm{C}_{\operatorname{man}}$ & $P_{\operatorname{man}}$ & Posm \\
\hline $\min$ & $m l / m i n$ & $\mu O s m / m l$ & $m l / m i n$ & $m l / m i n$ & $\underset{\min }{\mu \mathrm{Q} / \mathrm{ml} /}$ & $\underset{\min }{\mu E q / m l /}$ & $m g / \min$ & $m l / m i n$ & $\begin{array}{l}m g / \\
100 ~ m l\end{array}$ & $\mu O s m / m l$ \\
\hline $\begin{array}{l}-300 \\
-280\end{array}$ & & \multicolumn{9}{|c|}{$\begin{array}{l}500 \mathrm{ml} \text { of } 10 \% \text { mannitol with iv aqueous Pitressin at about } 25 \mathrm{ml} \text { per minute } \\
\text { Constant infusion } 10 \% \text { mannitol with aqueous Pitressin at } 80 \text { drops per minute }\end{array}$} \\
\hline-153 to -131 & 6.6 & 518 & 12.0 & 5.4 & 35.2 & 11.0 & 355 & 125 & \multirow{3}{*}{\multicolumn{2}{|c|}{$\begin{array}{l}286 \\
273\end{array}$}} \\
\hline-131 to -116 & 6.3 & 525 & 11.6 & 5.3 & 39.0 & 10.3 & 313 & 115 & & \\
\hline-116 to -100 & 6.9 & 516 & 12.5 & 5.6 & 43.5 & 10.7 & 350 & 127 & & \\
\hline-100 to -85 & 7.5 & 420 & 13.5 & 6.1 & 41.2 & 10.6 & 392 & 140 & \multirow[t]{2}{*}{280} & \multirow[t]{2}{*}{283} \\
\hline-85 to -70 & 6.5 & 520 & 11.9 & 5.4 & 40.5 & 11.7 & 325 & 109 & & \\
\hline-70 to -55 & 6.4 & 525 & 11.8 & 5.4 & 38.6 & 11.5 & 348 & 116 & \multicolumn{2}{|l|}{301} \\
\hline-55 to -40 & 6.8 & 523 & 12.4 & 5.6 & 39.7 & 10.9 & 378 & 122 & \multirow{3}{*}{317} & \multirow{3}{*}{284} \\
\hline-40 to -20 & 6.4 & 529 & 11.9 & 5.5 & 36.3 & 10.5 & 372 & 117 & & \\
\hline-20 to $\quad 0$ & 6.2 & 536 & 11.7 & 5.5 & 34.2 & 10.4 & 362 & 117 & & \\
\hline \multicolumn{11}{|c|}{$40 \mathrm{mg}$ iv methyl prednisolone } \\
\hline $\begin{array}{r}0 \text { to }+20 \\
+20 \text { to }+40\end{array}$ & $\begin{array}{l}6.0 \\
5.6\end{array}$ & $\begin{array}{l}546 \\
563\end{array}$ & 11.6 & $\begin{array}{l}5.6 \\
5.5\end{array}$ & $\begin{array}{l}34.2 \\
34.6\end{array}$ & 9.1 & $\begin{array}{l}344 \\
340\end{array}$ & 114 & 295 & 284 \\
\hline+40 to +60 & $\begin{array}{l}5.0 \\
5.4\end{array}$ & 579 & 11.0 & $\begin{array}{l}5.3 \\
5.6\end{array}$ & $\begin{array}{l}34.0 \\
30.5\end{array}$ & $\begin{array}{l}9.3 \\
9.4\end{array}$ & 347 & 110 & 336 & 283 \\
\hline+60 to +80 & 5.6 & 590 & 11.4 & 5.9 & 28.6 & 10.5 & 359 & 107 & & \\
\hline+80 to +100 & 5.4 & 602 & 11.5 & 6.1 & 26.1 & 10.8 & 371 & 115 & 306 & 284 \\
\hline+100 to +120 & 5.2 & 615 & 11.3 & 6.1 & 23.3 & 7.4 & 370 & 120 & & \\
\hline $\begin{array}{l}+120 \text { to }+135 \\
+135 \text { to }+150\end{array}$ & 5.5 & 625 & 12.1 & 6.6 & 21.2 & 8.9 & $\begin{array}{l}405 \\
308\end{array}$ & & & \\
\hline & 5.4 & 628 & 11.9 & 0.5 & 21.3 & 9.2 & 398 & & & \\
\hline
\end{tabular}

TABLE III

Effect of iv methyl prednisolone $(M P)$ on electrolyte, solute, and water reabsorption during osmotic diuresis in the dehydrated state*

\begin{tabular}{|c|c|c|c|c|c|c|}
\hline Patient & & $\mathrm{U}_{\mathrm{Na}} \mathrm{V}$ & $\mathrm{T}^{\mathrm{o}} \mathrm{H}_{2 \mathrm{O}}$ & $U_{K} V$ & Cosm & $\mathrm{C}_{\operatorname{man}}$ \\
\hline $\begin{array}{r}\text { no. } \\
7\end{array}$ & $\begin{array}{l}\text { Control } \\
\text { MP }\end{array}$ & $\begin{array}{c}\mu E q / \min \\
81 \\
50\end{array}$ & $\begin{array}{c}m l / \min \\
3.5 \\
4.4\end{array}$ & $\begin{array}{c}\mu E q / \min \\
86 \\
78\end{array}$ & $\begin{array}{c}m l / m i n \\
8.1 \\
8.3\end{array}$ & $\begin{array}{c}m l / m i n \\
119 \\
110\end{array}$ \\
\hline 8 & $\begin{array}{l}\text { Control } \\
\text { MP }\end{array}$ & $\begin{array}{l}57 \\
38\end{array}$ & $\begin{array}{l}1.7 \\
2.1\end{array}$ & $\begin{array}{l}112 \\
120\end{array}$ & $\begin{array}{l}5.7 \\
6.3\end{array}$ & $\begin{array}{l}124 \\
128\end{array}$ \\
\hline 9 & $\begin{array}{l}\text { Control } \\
\text { MP }\end{array}$ & $\begin{array}{r}130 \\
63\end{array}$ & $\begin{array}{l}2.7 \\
3.2\end{array}$ & $\begin{array}{l}136 \\
104\end{array}$ & $\begin{array}{l}7.2 \\
7.0\end{array}$ & $\begin{array}{l}48 \\
51\end{array}$ \\
\hline 10 & $\begin{array}{l}\text { Control } \\
\text { MP }\end{array}$ & $\begin{array}{l}220 \\
154\end{array}$ & $\begin{array}{l}0.5 \\
1.1\end{array}$ & $\begin{array}{l}202 \\
180\end{array}$ & $\begin{array}{l}7.2 \\
8.1\end{array}$ & $\begin{array}{l}49 \\
48\end{array}$ \\
\hline 11 & $\begin{array}{l}\text { Control } \\
\text { MP }\end{array}$ & $\begin{array}{l}665 \\
425\end{array}$ & $\begin{array}{l}3.5 \\
4.2\end{array}$ & $\begin{array}{l}158 \\
152\end{array}$ & $\begin{array}{l}10.9 \\
10.9\end{array}$ & $\begin{array}{l}127 \\
103\end{array}$ \\
\hline 12 & $\begin{array}{l}\text { Control } \\
\text { MP }\end{array}$ & $\begin{array}{l}683 \\
642\end{array}$ & $\begin{array}{l}2.7 \\
3.0\end{array}$ & $\begin{array}{l}77 \\
93\end{array}$ & $\begin{array}{r}9.9 \\
10.2\end{array}$ & \\
\hline 13 & $\begin{array}{l}\text { Control } \\
\text { MP }\end{array}$ & $\begin{array}{l}435 \\
294\end{array}$ & $\begin{array}{l}5.5 \\
6.1\end{array}$ & $\begin{array}{l}125 \\
106\end{array}$ & $\begin{array}{l}11.8 \\
11.3\end{array}$ & $\begin{array}{l}118 \\
114\end{array}$ \\
\hline $\begin{array}{l}\text { Mean difference } \pm 1 \mathrm{SE} \\
\quad(\mathrm{MP}-\text { control })\end{array}$ & & $-86 \pm 32$ & $+0.6 \pm 0.07$ & $-7.6 \pm 5.1$ & $-0.1 \pm 0.06$ & $-5 \pm 3.6$ \\
\hline
\end{tabular}

* Values used for the control periods were the means of collections from 0 to 60 minutes before the drug was given. Values for MP were the means of collections from 60 to 120 minutes after the drug.

0.13 (1 SD) for 60 clearance periods measured in the eight patients. ${ }^{2}$

Since mannitol, which accounted for 60 to $80 \%$

${ }^{2}$ Corcoran and Page reported a $\mathrm{C}_{\operatorname{man}}$ : $\mathrm{C}_{\mathrm{in}}$ ratio equal to 0.92 (11). These clearances, however, were presumably carried out with a considerably smaller filtered load of mannitol. of solute excretion, was excreted at a constant rate in these experiments, $\mathrm{C}_{\text {osm }}$ remained relatively constant throughout the studies (Tables II and III). A small decrease in $\mathrm{C}_{\text {osm }}$ was sometimes noted when a pronounced increase in sodium reabsorption was produced, or when $\mathrm{C}_{\operatorname{man}}$ diminished. 
No significant change in $\mathrm{C}_{\operatorname{man}}$ (or $\mathrm{C}_{\mathrm{in}}$ when measured) was noted after methyl prednisolone (Table III). In most patients, $\mathrm{C}_{\text {man }}$ fell slightly after drug administration; however, a similar fall was also noted during a rapid mannitol infusion in control experiments where no steroid was given, and it therefore was probably unrelated to steroid (Figure 8).

\section{DISCUSSION}

Methyl prednisolone increases the maximal ability to conserve free water in patients with cirrhosis of the liver on a low-salt diet. This improvement as measured by changes in $\mathrm{T}^{\mathrm{c}} \mathrm{H}_{2} \mathrm{O}$ formation was consistently observed after both acute and chronic administration of the drug. These findings are consistent with data reported in saltrestricted dogs exhibiting a decreased $\mathrm{T}_{\mathrm{H}_{2} \mathrm{O}}^{\mathbf{c}}$ (12). In these dogs, acute and chronic glucocorticoid administration was also associated with increased $\mathrm{T}^{\mathrm{c}} \mathrm{H}_{2} \mathrm{O}$ formation (12). While chronic administration was associated with a mild sodium diuresis in the present study, acute administration was always associated with substantial sodium retention and no change in potassium excretion. [These findings contrast with the findings of increased potassium excretion, no change in $\mathrm{T}^{\mathrm{c}} \mathrm{H}_{2} \mathrm{O}$, and increased sodium reabsorption when $d$-aldosterone is given under the same acute experimental conditions (13).] It appears likely that the attempt to demonstrate sodium retention during these acute studies was successful because large quantities of sodium were delivered by osmotic diuresis from the proximal to the distal nephron where glucocorticoids appear to act. The slight natruresis noted with chronic steroid administration is difficult to evaluate, since one does not usually observe this finding in patients with fluid retention when these agents are given alone $(3,5)$. Frequent administration of Pitressin and mannitol during chronic steroid administration may have affected the 24-hour data. Furthermore, interpretation of chronic studies is difficult, since numerous parameters of renal function cannot be continuously followed.

The associated findings of sodium retention and increased $\mathrm{T}^{\mathbf{c}} \mathrm{H}_{2} \mathrm{O}$ formation, when the drug is given acutely, could be explained, according to current concepts of renal physiology, by postulating that glucocorticoids act primarily to increase sodium reabsorption in the ascending loop of Henle, a segment of the tubule relatively impermeable to water. By enhancing delivery of sodium to the medullary interstitium, the hormone thus could contribute to the extraction of more solute-free water from the collecting duct.

An alternate hypothesis is that there is a direct effect of this agent on the collecting duct to increase water permeability. If this were so, it would be necessary to explain the decreased sodium excretion observed in these present experiments by an independent action. Since available data suggest that fluid in the collecting duct reaches osmotic equilibrium with fluid in the surrounding medullary interstitium, an effect of glucocorticoid on permeability could alter water reabsorption only if there were decreased collecting duct permeability in these patients. Goldsmith and associates have postulated such a defect in saltrestricted dogs (12). It does not appear likely, however, that glucocorticoids act by increasing collecting duct permeability, since other studies have shown that in the hydrated state, glucocorticoids produce more free water excretion, suggesting that these agents render the tubule less permeable to water $(3,7,14)$.

A decrease in medullary blood flow might also account for increased $\mathrm{T}^{\mathrm{c}} \mathrm{H}_{2} \mathrm{O}$ formation by leading to further sodium trapping in the medulla. Decreased medullary blood flow is not known to increase sodium reabsorption, so that in this case also, two independent actions would be required for this explanation. While this study does not rule out either alternative hypothesis, both seem less likely than the initial one presented, since this latter hypothesis could explain both sodium retention and increased $\mathrm{T}^{\mathrm{c}} \mathrm{H}_{2} \mathrm{O}$ formation.

The findings of increased $\mathrm{U}_{\max }$ and $\mathrm{T}^{\mathrm{c}}{ }_{\mathrm{H}_{2} \mathrm{O}}$ with chronic methyl prednisolone administration correlate well with the acute findings. While it is reasonable to assume that the mechanism responsible for the acute action is at least partially responsible for the rise in $\mathrm{T}^{\mathrm{c}} \mathrm{H}_{2} \mathrm{O}$ and $\mathrm{U}_{\max }$ with chronic drug administration, other factors may well contribute.

Four of the patients studied were in apparent complete remission of their disease. Since their response to glucocorticoid was similar to the response of the other patients, the data suggest that the findings reported are not restricted to patients 
with active cirrhosis. Nevertheless, it cannot be stated whether the mechanism responsible for the production of increased $\mathrm{T}^{\mathrm{c}} \mathrm{H}_{2} \mathrm{O}$ in these salt-restricted subjects was also responsible for the same findings reported with glucocorticoid in salt-restricted dogs (12). It is also not clear from the data presented whether dietary salt restriction per se, which has been reported to decrease $\mathrm{T}^{\mathrm{c}} \mathrm{H}_{2} \mathrm{O}$ formation in normal man (15), is related to the action of glucocorticoid described above.

The postulated action of glucocorticoids in the ascending loop of Henle would at least in part explain the increased ability of patients with fluid retention to excrete free water after a water load (3) and may be related to other diuretic effects of these agents.

\section{SUM MARY}

Methyl prednisolone, given acutely to eleven patients and over a period of 8 days to three patients with cirrhosis of the liver, consistently increased $\mathrm{T}^{\mathrm{C}_{2} \mathrm{O}}$ formation. This effect, when the drug was given acutely, was associated with decreased sodium excretion and no change in potassium excretion.

The data are interpreted to indicate that the primary effect of this agent is to increase sodium reabsorption in the ascending loop of Henle. By enhancing delivery of more sodium to the medullary interstitium, the hormone contributes to the extraction of more solute-free water from the collecting duct in the presence of a maximal antidiuretic hormone stimulus.

\section{ACKNOWLEDGMENT}

We wish to thank Miss Ann Long and Mrs. Margaret Wilcox for supervising the care of the patients on the metabolic unit and Miss Sheila Dye for dietary supervision.

\section{REFERENCES}

1. Pechet, M. M., B. Bowers, and F. C. Bartter. Metabolic studies with a new series of 1,4-diene steroids. I. Effects in normal subjects of prednisone, prednisolone, and $9 \alpha$-fluoroprednisolone. J. clin. Invest. 1959, 38, 691.
2. Dingman, J. F., J. T. Finkenstaedt, J. C. Laidlow, A. E. Renold, D. Jenkens, J. P. Merrill, and G. W. Thorn. Influence of intravenously administered adrenal steroids on sodium and water excretion in normal and addisonism subjects. Metabolism 1959, 7, 608 .

3. Kessler, E., J. G. Hilton, and M. R. Levy. Renal and adrenal relationships in refractory edema. Circulation 1962, 26, 12.

4. Carbone, J. V., and H. B. Matthews. The use of prednisone to initiate or potentiate diuresis in chronic hepatic disease with ascites. Gastroenterology 1960, 38, 52.

5. Morrison, R. S., and T. C. Chalmers. Combined diuretic and steroid therapy in cirrhosis with ascites. Ann. N. Y. Acad. Sci. 1960, 88, 907.

6. Stormont, J. M., J. Crabbe, B. Fast, S. J. Wolfe, and C. S. Davidson. The effect of prednisone and amphenone on fluid and electrolyte balance and on aldosterone excretion of patients with cirrhosis and ascites. J. Lab. clin. Med. 1959, 53, 396.

7. Raisz, L. G., W. F. McNeely, L. Saxon, and J. D. Rosenbaum. The effects of cortisone and hydrocortisone on water diuresis and renal function in man. J. clin. Invest. 1957, 36, 767.

8. Dingman, J. F., and R. H. DesPoints. Adrenal steroid inhibition of vasopressin release from the neurohypophysis of normal subjects and patients with Addison's disease. J. clin. Invest. 1960, 39, 1851.

9. Lindeman, R. D., H. C. Van Buren, and L. G. Raisz. Effect of steroids on water diuresis and vasopressin sensitivity. J. clin. Invest. 1960, 40, 152.

10. Higashi, A., and L. Peters. A rapid colorometric methed for the determination of inulin in plasma and urine. J. Lab. clin. Med. 1950, 35, 475.

11. Corcoran, A. C., and I. H. Page. A method for determination of mannitol in plasma and urine. $\mathrm{J}$. biol. Chem. 1947, 170, 165.

12. Goldsmith, C., H. K. Beasley, P. J. Whalley, F. C. Rector, Jr., and D. W. Seldin. The effect of salt deprivation on the urinary concentrating mechanism in the dog. J. clin. Invest. 1961, 40, 2043.

13. Jick, $H$. Unpublished data.

14. Kleeman, C. R., M. H. Maxwell, and R. E. Rockney. Mechanisms of impaired water excretion in adrenal and pituitary insufficiency. I. The role of altered glomerular filtration rate and solute excretion. J. clin. Invest. 1958, 37, 1799.

15. Stein, R. M., B. H. Levitt, M. H. Goldstein, J. G. Porush, G. Eisner, and M. F. Levitt. The effects of salt restriction on the renal concentrating operation in normal, hydropenic man. J. clin. Invest. 1962, 41, 2101. 